\title{
Socioeconomic Response to Water Quality: a First Experience in Science and Policy Integration for the Izmit Bay Coastal System
}

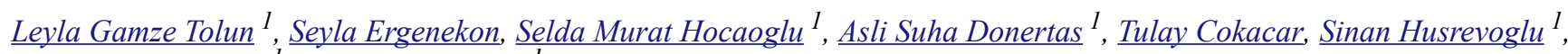 \\ Colpan Polat Beken $^{1}{ }^{1}$, and Ahmet Baban ${ }^{1}$
}

\begin{abstract}
Deterioration of the Izmit Bay ecosystem, mainly caused by heavy industrialization and urbanization, has significantly impaired its beneficial use and resulted in the surrounding coastal zone losing its attractiveness for the inhabitants. An integrated coastal zone management approach has become an important requirement of future development plans to protect this fragile bay ecosystem. One of the main indicators of deterioration of the Izmit Bay coastal system is the decreasing water quality resulting from increased nutrient loads from the surrounding land.The consensus during the initial stakeholder meeting confirmed the widespread awareness of this phenomenon and "improvement of water quality in Izmit Bay" was determined as the main policy issue at stake. Public perception of and satisfaction with water quality were measured by a willingness to pay (WTP) survey. The WTP for improved water quality was analyzed using the contingent valuation method. According to the questionnaire survey, $55 \%$ of the participants are willing to pay to increase the water quality. Impact of water quality on realestate values was evaluated by hedonic pricing method, which is suitable for estimating direct and indirect use values of water resources. These results were used in a simulation model to assess coupled ecosystem, social, and economic system functioning of the Izmit Bay in response to various scenarios, and thus, to permit the necessary actions to be taken proactively. Two scenario simulations, for which domestic and runoff nitrogen loads are reduced independently, showed that hypothetical domestic wastewater treatment resulted in an improvement in simulated water transparency. The results suggest that domestic wastewater treatment should be a first priority for local administrations.
\end{abstract}

Key Words: integrated coastal zone management; Izmit Bay; stakeholder interaction; socioeconomic analysis; systems approach

\section{INTRODUCTION}

Coastal areas are social-ecological systems that include both human and ecosystem components (Berkes and Folke 1998). Understanding and managing these systems, therefore, requires an integrative approach that includes multiple disciplines, such as economics, sociology, and ecology. Integrated coastal zone management (ICZM) has been recommended by the European Union (EU), as an approach to facilitate sustainable development in coastal areas. By signing the Barcelona and Bucharest conventions in 1981 and 1993, respectively, the Republic of Turkey has committed itself to implementation of ICZM (Algan 2000).

Stakeholder participation is an essential part of ICZM, demonstrating its value in management decisions (European Commission (EC) 1999). Communicating with the public is also essential; however, this is not a common practice in Turkey, as it is in many EU coastal states. Gaps in Turkish environmental legislation have slowed the implementation of this holistic, participatory, and multidisciplinary approach to coastal zone management. Although some effort has been made to improve coastal zone management practices using an integrative approach (Ozhan 2005), progress has been limited mainly due to the lack of spatial planning and a holistic viewpoint.

Furthermore, one of the main policy objectives in the EU legislation is to prevent further deterioration and to protect and enhance the status of aquatic ecosystems. Under the framework of harmonization with the EU legislation at the national level, Turkey will be required to adopt the Water Framework Directive (EC 2000), and the Marine Strategy Framework Directive (EC 2008). The successful implementation of these directives and ICZM (EC 2002) in Turkey requires adaptation of the ecosystem approach for management of its seas and coasts. However, the abovementioned restrictions need to be resolved, and public outreach and knowledge are required to communicate the importance of Turkey's coastal ecosystem and its susceptibility to anthropogenic impacts.

Implementation of a "Sustainable Development Strategy" at the national level is one of Turkey's priorities (Government of Turkey 2001). In order for this to be a successful strategy at the local level, a common language is needed to support interdisciplinary communications, and the importance of ecological, social, and economic functions of the related systems has to be better recognized.

\section{Purpose of this study}

This article concerns an application of the Systems Approach Framework (SAF) in the Izmit Bay as one of 18 coastal zone systems (CZS) that participated in the development and testing of the SAF by the EU Project, Science and Policy Integration for Coastal System Assessment (SPICOSA) (cf. Hopkins et 
al. 2011). The SAF is an adaptation of the systems approach (Kelly 1998) to provide a methodological tool for ICZM. It is an open methodology that uses simulation analysis integrating the ecological, social, and economic (ESE) dimensions and stakeholder engagement to evaluate policy scenarios relating to sustainable development (Hopkins et al. 2011, Tett et al. 2011). As such, it attempts to upgrade and improve the interface between scientific knowledge and coastal environmental policy; specifically, it offers information to decision makers by conducting a simulation analysis of a policy issue together with scenarios for its resolution while engaging stakeholders and policy in the process.

The purpose of this paper is to describe aspects of the SAF application to Izmit Bay. Our policy issue (PI), decided upon by policy makers, stakeholders, and researchers, concerned the options for reducing the impacts of nitrogen loading into the Bay, with the goal of improving the Bay's water quality. The scenarios associated with this policy issue concerned:

- How do the point and non-point discharges of nutrients and suspended solids affect the water quality?

- What changes and costs would be involved in ensuring an acceptable water quality?

- Are there sufficient public interest and a justifiable means to support the necessary costs?

This study, which was conducted to test the SAF with only existing data and expertise, is the first attempt for the Izmit Bay to execute such an extensive multidisciplinary assessment and stakeholder involvement. The three aspects emphasized in this article are:

- Simulation analysis as a tool for understanding of the ecosystem responses to different nutrient-loading scenarios;

- Socioeconomic assessments as a means of demonstrating non-market qualities in resource management decision making; and

- Stakeholder engagement as an integral and necessary part of management decision making.

\section{IZMIT BAY COASTAL ZONE}

Izmit Bay $\left(40^{\circ} 45^{\prime} \mathrm{N}, 29^{\circ} 56^{\prime} \mathrm{E}\right)$ is the easternmost extension of the Marmara Sea (Fig. 1), covering a surface area of 310 $\mathrm{km}^{2}$ (Basturk et al. 1985). The total volume of the Bay is ca. $18 \mathrm{~km}^{3}$, and the residence time of the surface layer $(0-40 \mathrm{~m})$ is estimated to be 10 to $15 \mathrm{~d}$ (Ediger et al. 2009, SPICOSA project unpublished data ). The bay is tectonically formed and comprises three basins connected by narrow passages. Maximum water depth is ca. $25 \mathrm{~m}$ in the eastern basin, and ca. $200 \mathrm{~m}$ in the central and the western basins. The water column is characterized by three vertical layers. A strong pycnocline at around a depth of $25 \mathrm{~m}$ separates the lower salinity waters
$(18-21 \%)$ originating from the Black Sea from the higher salinity waters (38-39\%o) of the Mediterranean (Basturk et al. 1985, 1990).

Fig. 1. (Top panel) Location of Izmit Bay $\left(40^{\circ} 45^{\prime} \mathrm{N}, 29^{\circ}\right.$ $56^{\prime} \mathrm{E}$ ) in the Marmara Sea and (bottom panel) the locations of main freshwater input source points (domestic and industrial discharge, rivers, and creeks), and the passage providing water exchange between the western and central basins of the bay. Satellite image was obtained from Google Earth.
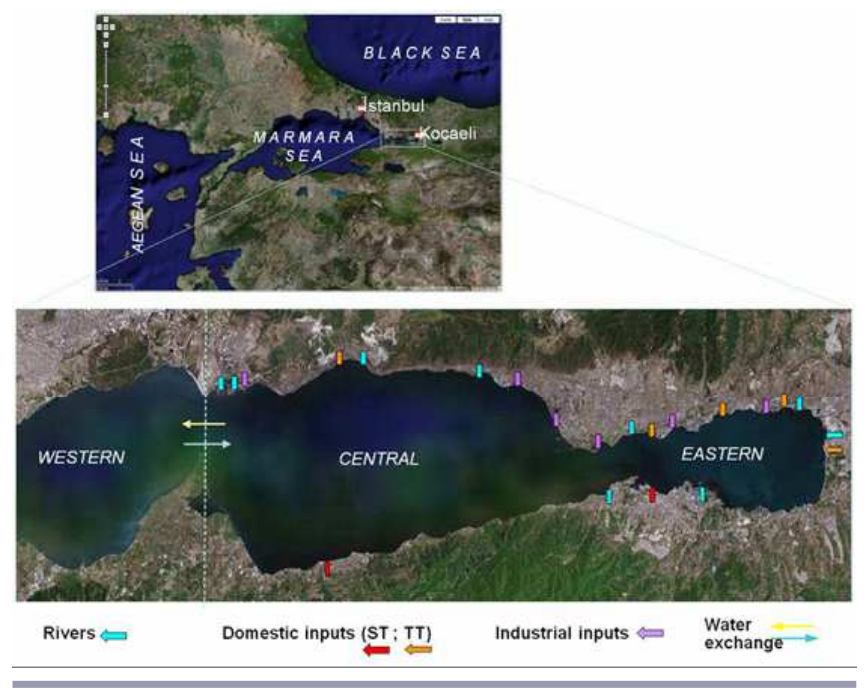

\section{Ecosystem goods and services}

The coastal ecosystem functions are described by Millennium Ecosystem Assessment (MEA 2003) and The Economics of Ecosystems and Biodiversity (TEEB 2010); we summarize them for Izmit Bay as:

- Seafood. Despite the anthropogenic pollution, national legislation considers this region as an aquatic production area. However, fishing is not an important economic activity due to the loss of valuable fish. Mediterranean mussels (Mytilus galloprovincialis) grow wild along the coast, especially near discharges, but are not edible because of the pollution.

- Natural amenities. Before the 1970s, the clear waters of Izmit Bay were very attractive for recreation activities, and Izmit and Hereke were famous sailing towns (Fig. 2). These leisure activities are decreasing every year because of the decline in the coastal water quality. The urbanization (physical growth of urban area) of the coastal landscape has diminished the previous serenity of the Bay.

- Coastal tourism. There are still several local tourism centers in the southern region of the Bay. Until the present 
study, the link between tourist visits and environmental condition of this coastal system had not been analyzed, yet it seems clear that the dominance of industrial activities must have an adverse effect on tourism in the region.

- Waste assimilation capacity. The Bay is the receiving body for most of the treated and untreated domesticindustrial wastewaters of the region. Due to the long residence times of the bottom waters, our simulation suggests an imminent risk of creating a costly anoxic condition in the deep Central basin.

- Provision of cultural amenities and spiritual value. The Izmit Bay, its coasts, and the enveloping skies are the spiritual heritage of all who live in their environment and a source of renewal and refreshment for the multitude who witness them. Mystics, artists, musicians, writers, and fishermen have responded to this throughout the ages.

- The Bay has also a great importance for scientists from different disciplines (environment, earth, and marine sciences) because of its geographic location and interesting oceanographic characteristics.

Fig. 2. Sailing as a recreational activity in Izmit Bay in the late 1930s. Photographs obtained from the Izmit Sports Club archive.

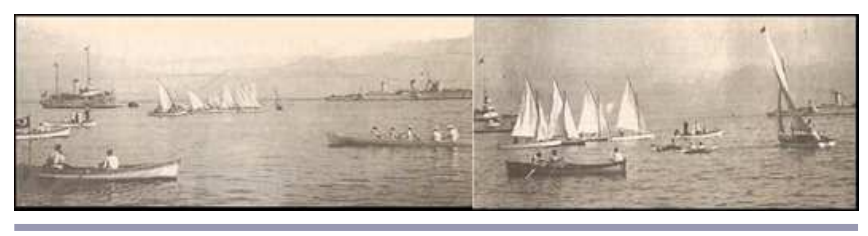

Drivers, pressures, state, impact, and response

Industrialization and population increase are the main anthropogenic drivers exerting pressure (Polat-Beken et al. 2009, Tolun et al. 2002). Rapid population growth has been reported in the region in the last $40 \mathrm{yr}$ (Polat-Beken et al. 2009). About two million people currently reside in the Izmit Bay coastal zone (Turkish Statistical Institute (Turkstat) 2009). The urbanization ratio and annual population growth of Kocaeli Province are 52\% and $2.5 \%$, respectively (TurkStat 2009). Industrialization has been rapid, with over 1,500 industrial plants established in the last $40 \mathrm{yr}$ (Tolun et al. 2002). Extensive harbor facilities are located around heavily industrialized towns. Most of the pollutant discharges occur via rivers and channels and are located on the northern shore (Fig. 1). Due to large increases in these domestic and industrial pollutant inputs (Tolun et al. 2002, 2003), the deterioration of the Bay's coastal waters has been an ever-increasing problem, causing extensive impacts.

A major environmental impact is hypoxia occurring for the intermediate and bottom layers of the central and inner basins (Okay et al. 2001, Balkis 2003, Ediger et al. 2009). Furthermore, since the 1970s, there has been a remarkable decrease in water transparency (Fig. 3) and an increase in harmful algal blooms, and, since 2007, massive mucilage formations have occurred (Okay et al. 2001, Polat-Beken et al. 2010, Tüfekç et al. 2010a, 2010b). The large variability in nutrient inputs has contributed to these planktonic events. The surface layer of the eastern and central parts of the bay is considered nitrogen limited in summer (Marmara Research Center 2010 unpublished data) and eutrophic throughout the year (Tuğrul et al. 1989, Morkoc et al. 1997, Ediger et al. 2009). The bay ecosystem was also affected by the 1999 earthquake, which created widespread damage, destroying almost all treatment facilities and causing a serious refinery fire (Okay et al. 2001). Investigations show that increased polychlorinated biphenyl (PCB) and polycyclic aromatic hydrocarbon (PAH) concentrations in the consumable mussels pose a risk for human health (Tolun et al. 2007).

Fig. 3. Decline of seawater transparency in the eastern, central, and western basins of Izmit Bay.

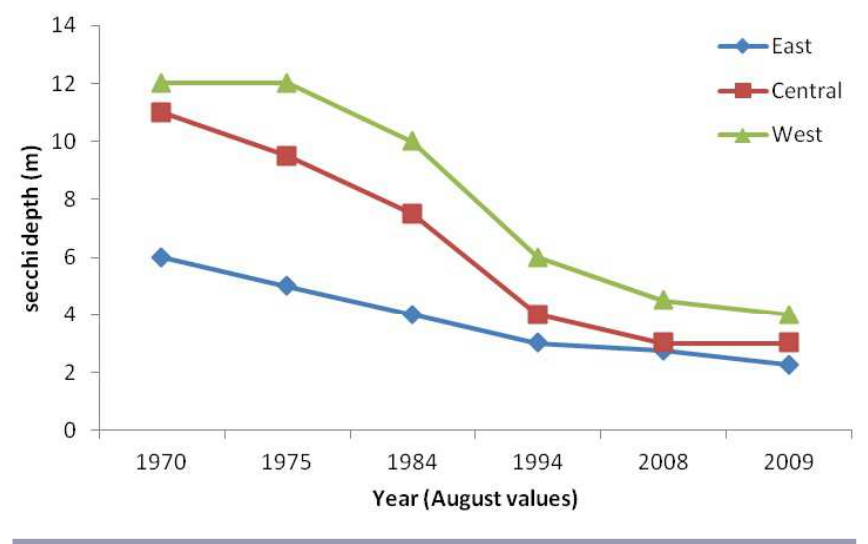

Until the National Environmental Law (NEL; Turkish Official Gazette 1983) was implemented, all the domestic and industrial wastewaters were discharged into the bay without treatment. Pollution prevention attempts decreased industrial organic carbon discharge (Morkoç et al. 2001). Following the revision of the NEL in 2006 (from 13 May 2006 onward, sections 10,12 , and 14 et seq.), industries have increasingly been required to fulfill the conditions stated in the environmental legislation. Municipal wastewater treatment plants (WWTPs) are centrally located in residential areas around the bay (Fig. 1). The WWTPs normally receive raw domestic wastewater and storm water. Combined sewage outflows (CSOs) are also used for flow regulation to WWTPs. 
Treated wastewater is directed to the bay as a point source. Some municipal WWTPs have nitrification and denitrification units, but most of the domestic WWTPs only remove organic matter, and therefore, nutrient loading remains a problem. In addition, the surface runoff from agricultural or recreational activities to receiving basins, rivers, etc. constitutes an additional source of nutrients, suspended matter, and other forms of pollutants. Currently, ca. 0.3 and $6 \mathrm{t}$ of nitrogen/day is discharged into the Bay from industrial and domestic sources, respectively (Fig. 4) (Avaz et al. 2011). A continuous effort is being made to cover all residential areas with sewage networks and to construct new WWTPs for carbon and nutrient removal as an end-of-pipe treatment approach.

Fig. 4. Variability of total nitrogen loads from domestic sources (1984-2010) discharged into Izmit Bay.

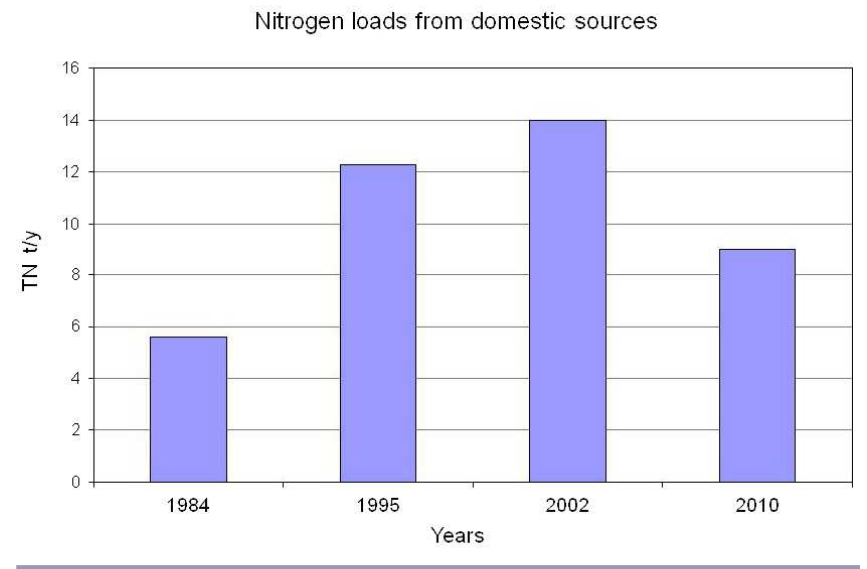

\section{METHODS}

\section{System simulation}

A conceptual model was constructed to simulate the major coupled functionalities of the Izmit Bay coastal system described above. The model, designed using an end-to-end approach, included the three ESE components, i.e., as an ecosystem module linked to a social-economic module (Fig. $5)$.

The ecosystem module was constructed as a time-dependent biogeochemical model linked with the circulation system, using ExtendSim ${ }^{\mathrm{TM}}$, a commercial simulation software. The circulation model considered Izmit Bay as a single horizontal entity with the eastern and central basins combined and with three vertical layers: (1) the surface layer outflowing to Marmara, (2) the intermediate layer receiving the inflow over the sill (50 m), and (3) the deep layer relatively stagnant with some diffusive loss upward and occasional gain by denser inflow waters. The circulation module was forced by the zonal density gradient, obtained from a simplified calculation of the steric height difference between the inner bay and the Eastern
Marmara Sea (cf. Hopkins 2001). Atmospheric inputs included solar irradiance, wind, surface air temperature, precipitation, and humidity.

The biogeochemical module used nitrogen and total suspended solids (TSS) from land-based sources (domestic and industrial discharge, rivers, and runoff) as main inputs and provided the Secchi disk depth (SDD) as the primary output. The dynamic link between nutrient loads and SDD (turbidity) was simulated for the surface layer primary production (diatoms and dinoflagellates), zooplankton growth, and remineralization, dissolved oxygen, and particulate organic matter (POM). This module was connected to the circulation model and received additional inputs in the form of timedependent substance loading of nitrogen fluxes.

The social and economic components of the model were developed considering two of the secondary consequences from the impact response relationship diagram (Fig. 6). The socioeconomic component consisted of social and economic responses to water quality through a link with water transparency, indicated by SDD. The economic component was based on the indirect relationship between water quality and real-estate values in the coastal areas surrounding the bay.

\section{Socioeconomic response}

There are several methods in the literature for estimating the use and/or non-use values of ecosystem services (e.g., Pearce and Turner 1990, Turner 1993, Dixon et al. 1994, Pagiola et al. 2004). Izmit Bay provides services to the public and individuals, thus, we focused not only on its present use value but also on its non-use value. The reduced water quality has impacts both on manufactured capital (housing prices) and social capital (people's preferences and satisfaction) (Fig. 7). If pollution of the bay is reduced, both manufactured capital and social capital will increase. Hedonic pricing analysis (HPA) and contingent valuation (CV) constitute two ways of estimating social and economic (market and non-market) benefits; the former estimates use values, and the latter estimates both use and non-use values of improved water quality. We used both methods to evaluate the resulting social and economic benefits, as described in detail below (Fig. 8).

\section{Hedonic pricing analysis (HPA)}

Hedonic pricing analysis is used to estimate an implicit price for environmental characteristics by looking at real markets in which those characteristics are effectively traded. It assumes that a house in a clean environment will have a higher market value than an identical one located in a polluted area (Lancaster 1966, Pearce 1993, Garrod and Willis 1999). This method needs a large number of observations in order to make a correlation between the price and the environmental factor (water clarity in our case). The price of a house is determined through a regression analysis that relates the price of the property to its characteristics, and the environmental characteristic of interest. The regression results indicate how 
Fig. 5. The feedback loop involving the ecosystem, social, and economic (ESE) modules of the simulated system. The ecosystem components of the simulated system are embedded in an underlying circulation module (not shown in the schematic), which resolves the domain in three vertical layers.

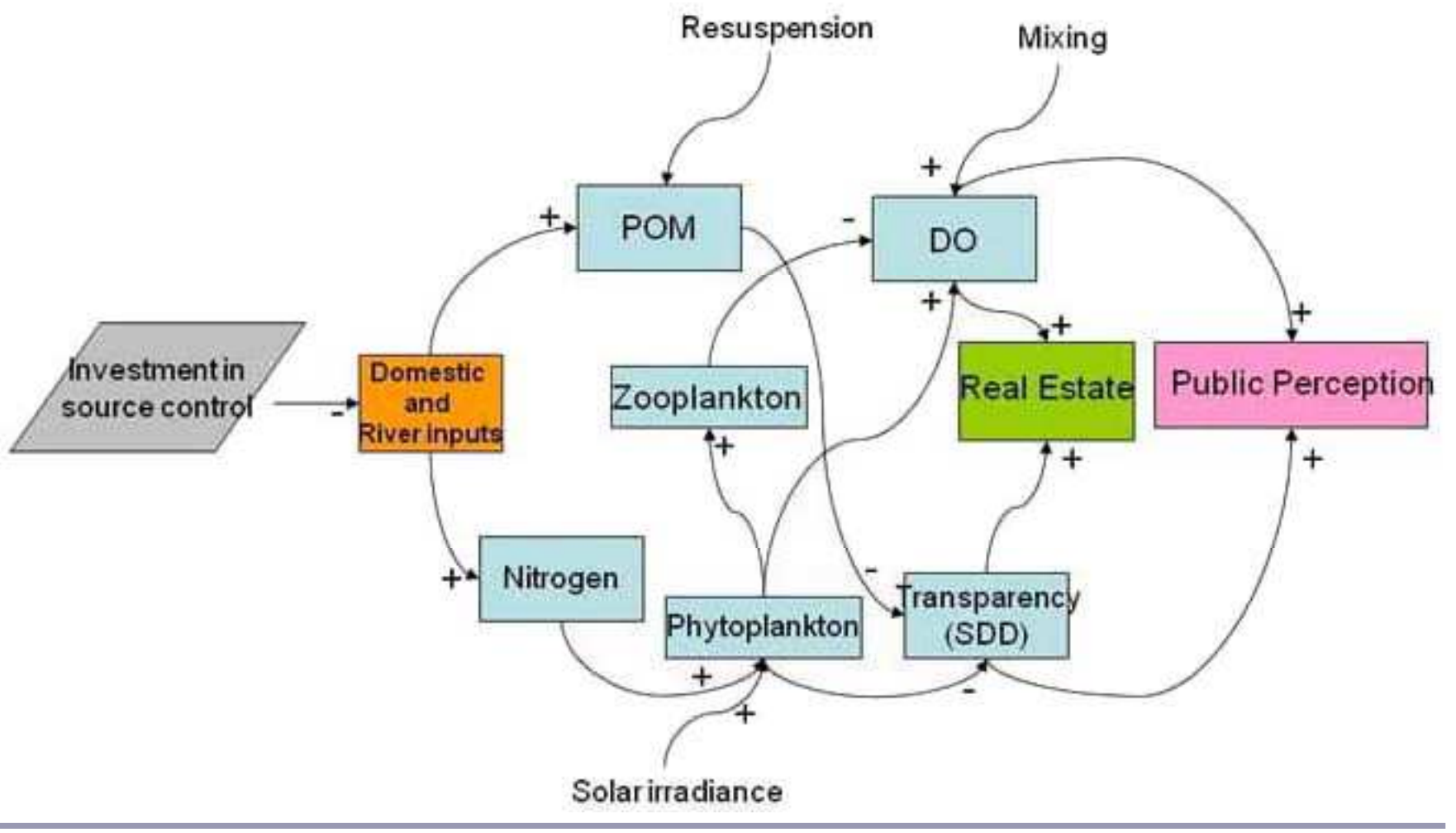

much property values will change for a small change in each characteristic, holding all other characteristics constant. Brashares (1985) considered eight different parameters of water quality and found that only turbidity (which is comparable to SDD measurements of clarity used in this study) and fecal coliform levels significantly correlated with property prices. More recently, Michael et al. (1996) were also concerned with poor water quality resulting from eutrophication in Maine lakes and showed the SDD measurements were those most easily discerned by the public. Secchi disk depth was also highly correlated with other indicators of eutrophication, such as dissolved oxygen, chlorophyll levels, fish habitat, and suitability for bathing.

In this study, we used HPA to determine the loss of economic benefit due to pollution, based on real-estate values (for more info, see http://www.spicosa.eu/studysites/index.htm). We selected SDD as an indicator of water transparency, something easily observed by local inhabitants, and assigned the SDD value of the nearest station to each apartment. The Marmara Research Center (MRC) Environment Institute (EI) offered water quality data from monitoring studies of Izmit Bay conducted by MRC-EI in 2001-2002 and 2008-2009 (Fig. 8). The information on the real-estate properties was collected from websites of real-estate agencies. Data regarding the price and physical properties of apartments (location, size, age, room number, floor, type of heating, whether has balcony, garden, parking area, sea view, etc.) were collected for 174 apartments for sale all around the bay (all by the seaside). A regression analysis was conducted using all available data.

\section{Contingent valuation method (CVM)}

The Contingent Valuation method is a stated preference technique that has the advantage of measuring both use and non-use values. In this method, people are asked directly how much they would be willing to pay for specific environmental services (Mitchell and Carson 1989, Pearce and Turner 1990, Pagiola et al. 2004). In this study, we conducted a CVM survey to draw a general picture of coastal use and collect information on activities that have both economic and social value. The main purpose of the survey was to predict the possible change in those activities if the water quality in Izmit Bay were to be improved and to measure the public's willingness to pay (WTP) for the improvement. Each consumer was also asked how much money he or she would be willing to pay for the improved water quality described in the questionnaires as transparency (SDD). From the analysis, the average value for a household was estimated and extrapolated to the coastal 
Fig. 6. Impact-response relationship in the Izmit Bay coastal system for the selected PI. Relationships considered by the SSA team are marked by red rectangles.

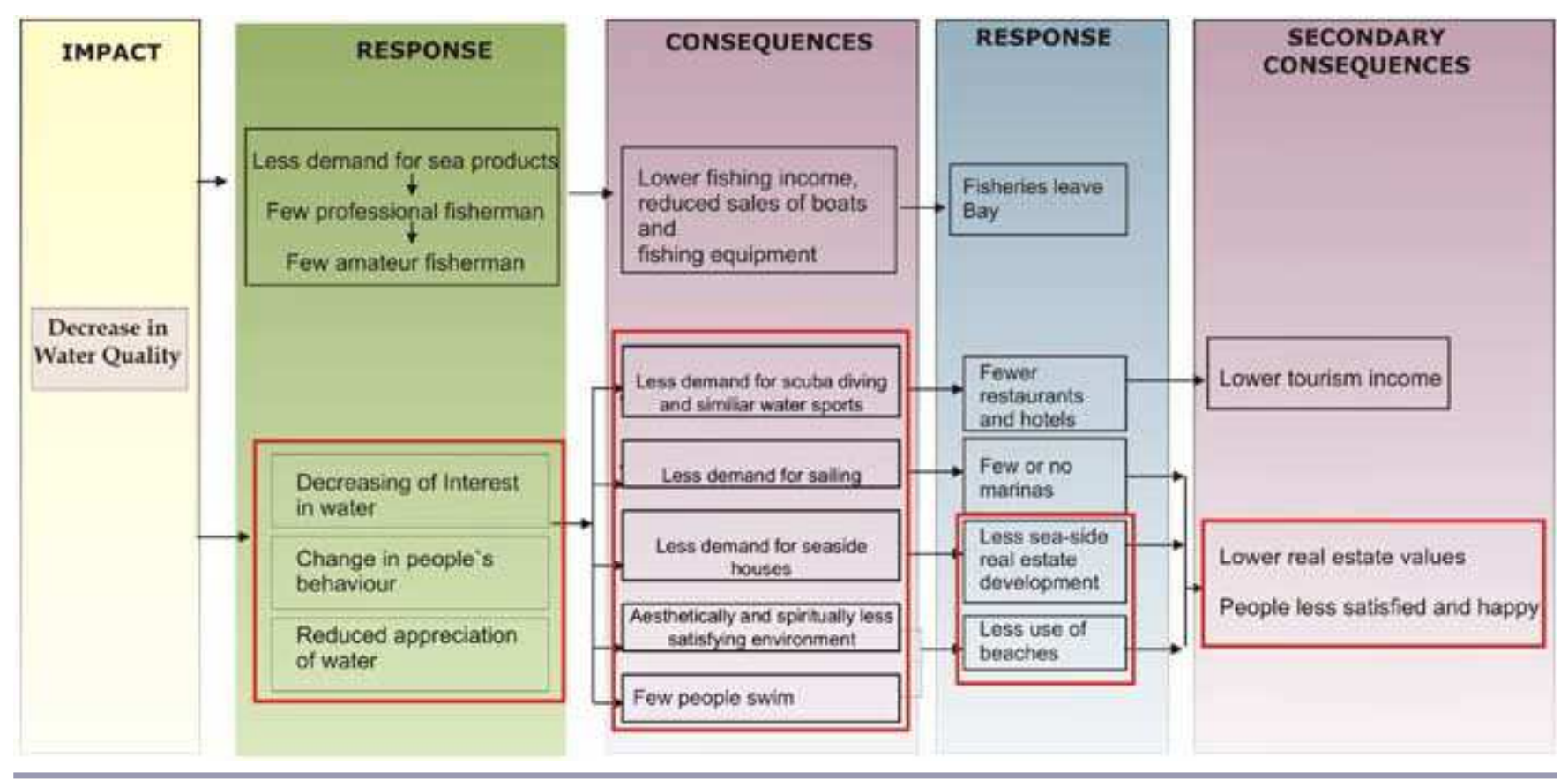

population in order to calculate the total benefits. In order to make a cost-benefit comparison, the average per capita willingness to pay figure was converted to average WTP for the advanced treatment of one cubic meter of wastewater, which was compared with the unit cost of treatment.

\section{Cost-Benefit analysis}

Cost-benefit analysis (CBA) is an important element of environmental policy making; a tool for determining the costs and benefits of a project, plan, policy, or economic activity in order to assess whether it should be implemented. The provision of an environmental good (benefit or improvement) or service entails a cost. Therefore, we must know both costs and benefits of the good or service in terms of money, because it is only then that we can find out whether its benefits would be greater than its costs. Two types (financial and economic) of CBA were carried out in this study. In the first scenario, treatment of the untreated (illegal) discharges, and upgrading of existing WWTPs would involve investment and operational costs. Investment costs include construction and machinery expenses, which would be spent at the beginning of the investment. Operational costs included expenses such as electricity and personnel costs, which would arise during the operation of the plant. Reducing wastewater discharges also provides a variety of benefits to human health, biodiversity of marine life, and esthetics, etc. However, there is no defined market value for such environmental goods and services, as described in the previous subsection. People appreciate some of these benefits, and they derive satisfaction from an improved quality of water (i.e., SDD, the output of ecosystem component). The approach in this study was to express the monetary value of less polluted seawater by conducting a CVM study.

\section{RESULTS}

\section{Stakeholder involvement: determination of the policy issue (PI) and scenarios}

Using the results from previous research studies (Tolun et al. 2002; Morkoç et al. 2007) and methodology described by Mayers and Vermeulen (2005), Aligica (2006), and Vanderlinden (2009), we prepared a preliminary list of human activities (HAs), and identified the stakeholders associated with these HAs (Fig. 9). The SPICOSA objectives and methodology were then presented and discussed with the Kocaeli Metropolitan Municipality and related departments. During this meeting, a list of relevant stakeholders (sectors/ institutions/persons) who should be invited to the first stakeholder meeting was produced in accordance with the main HAs in the region (such as urbanization, industrialization, and marine activities).

The first stakeholder meeting was organized in Kocaeli province, with participation from a variety of organizations. Distribution of the organizations was: 14\% public-district government, $15 \%$ public-central government, 14\% private sector, $14 \%$ public-local government, $7 \%$ public union, $14 \%$ 
Fig. 7. Conceptual diagram of the social and economic model for the Izmit Bay coastal system.

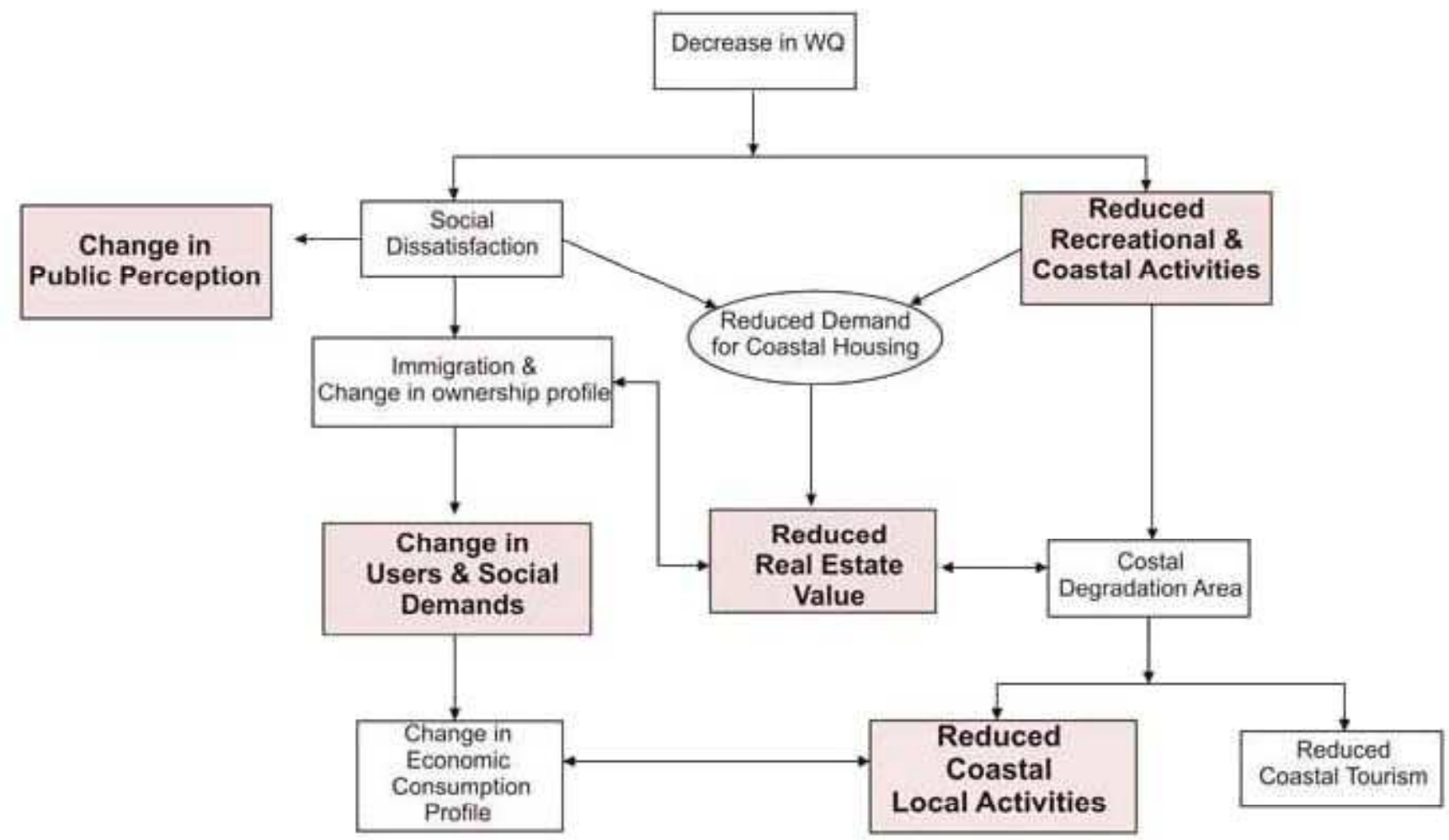

national and regional non-governmental organizations (NGOs), and 22\% research and development universities. Participants were active and solution oriented in discussions. However, there was no representation from the industrial sector or the local NGOs (Local Agenda 21 and the Society of Amateur Fishermen). This day-long meeting was intended to announce the project and to enhance participation of local and regional stakeholders. Thirty-six participants from 16 organizations undertook to: (a) reach an agreement on PI(s) and associated scenarios, indicators, descriptions, and water quality criteria and (b) identify what dysfunctions (impacts) in the natural system are implied by this PI and prioritize them in the case of multiple impacts. Additionally, pre-proposed impacts were discussed, voted, and ranked by participants, assigning them numbers from 1 to 5 according to level of priority. The outputs of the meeting and several "one-on-one" meetings (with policy makers, the local governor, universities, and the chamber of industry) were used to revise the PI and model scenarios.

Considering the prioritized impacts determined in the first stakeholder meeting, the second meeting began with the selection of "Improvement of Water Quality in Izmit Bay" as the PI, and the impact was specified as the decreased water quality due to increased domestic loads, such as nutrients and total suspended solids (TSS). For this PI, water quality indicators such as SDD and nitrogen were determined. Secchi disk depth changes since 1970 have shown that a considerable decline in water quality in all the basins of the Bay is evident (Fig. 3). Following the determination of the PI, an impactresponse relationship diagram was constructed concerning the responses to decreased water quality in Izmit Bay (Fig. 6.). According to this, there are several interrelated effects of decreased water transparency. One of the initial effects is reduced interest in developing the coastal area for residential and recreational facilities.

\section{Scenarios}

The main issues considered to be most important are nutrients, in the form of nitrogen compounds, and suspended solids. In relation to this, some of the current treatment facilities are not equipped to remove nutrients, and illegal domestic discharges should be of primary focus. Based on these considerations, the following two scenarios were developed:

\section{Reduction of the nitrogen loads by additional wastewater treatment of domestic sources.}

The scenario includes upgrading existing urban WWTPs to achieve reusable streams to be used mainly for irrigation (it would help mitigation of water scarcity and 
Fig. 8. A diagram of the structure of data and methods used for the social and economic components of the study.

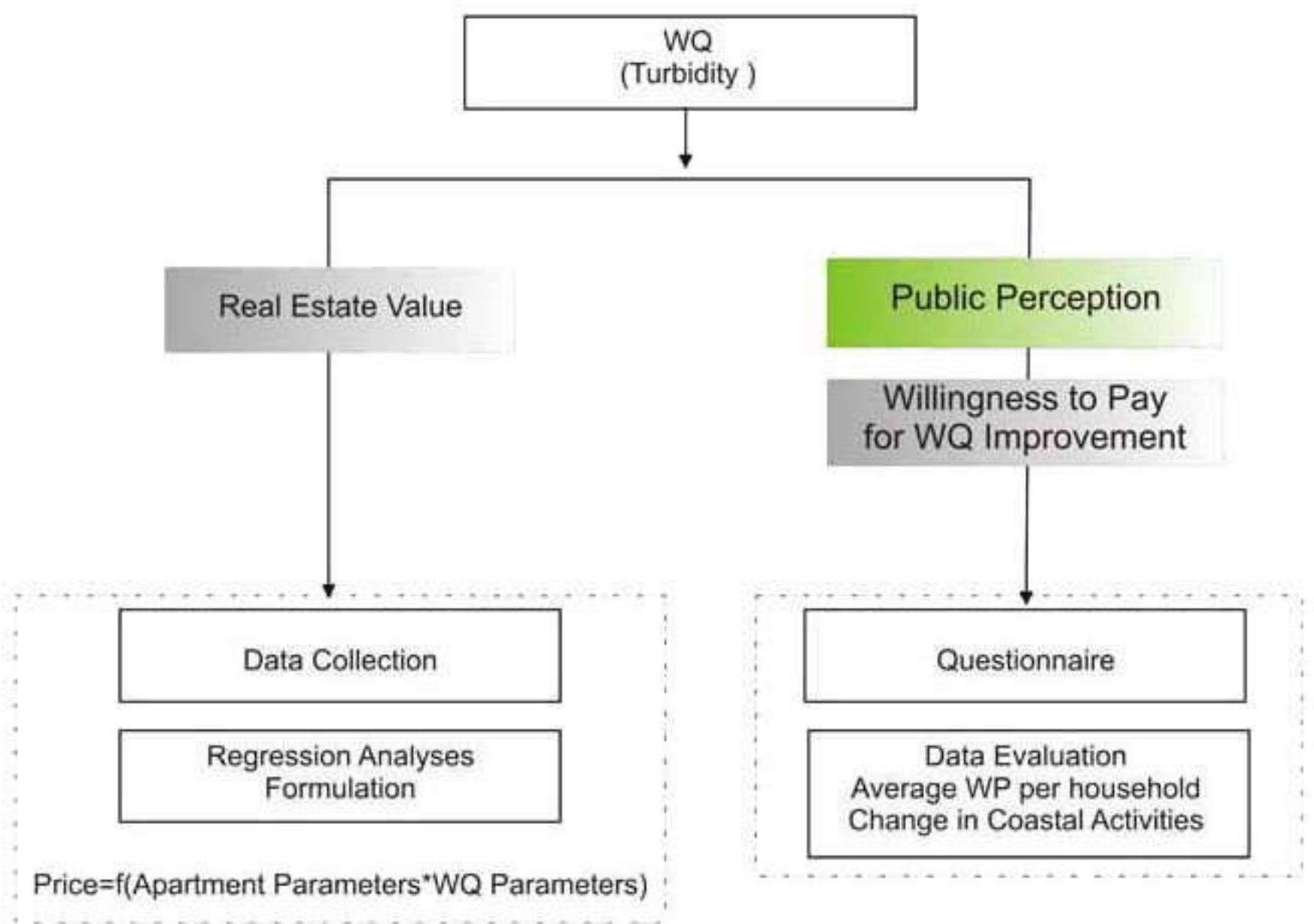

conservation of valuable water resources). Implementation of this scenario would result in a $550 \mathrm{~kg}$ /day decrease in total nitrogen (TN) load, which is equivalent to an $80 \%$ TN reduction for Golcuk and Karamursel settlement areas, which have a total population of 160,000 .

2. Decrease nitrogen loads reaching Izmit Bay due to runoff by applying integrated control technologies for rivers.

Surface runoff collection and treatment within the Dilderesi and Eastern Channel catchment basins was considered to mitigate a non-point source of pollution to coastal waters and to provide irrigation water. A $60 \%$ nitrogen removal efficiency was estimated, which corresponds to the reduction of $900 \mathrm{~kg} /$ day of TN due to runoff.

The cost assessment for the proposed scenarios was made by considering cost items such as capital and operation and maintenance costs (energy requirement, personnel, and consumables).

Representatives from the Kocaeli Metropolitan Municipality, General Directorate of Water and Wastewater Management, and Province Environmental Directorate of Kocaeli Governorate attended the third meeting because they were responsible for the eventual implementation of the scenario results and to make it easier for them to express their opinions and ideas. During the meeting, the first model results were presented and the scenarios were discussed. Participants had difficulty understanding the scientific basis of the model but showed great interest in the scenarios. Two scenarios were compared in terms of implementation difficulties and suitability for future plans and programs during the stakeholder meeting. Participants also provided valuable additional information that will be used to revise the scenarios accordingly. A user-friendly version of the model was 
Fig. 9. A diagram depicting the method followed to determine the Policy Issue.

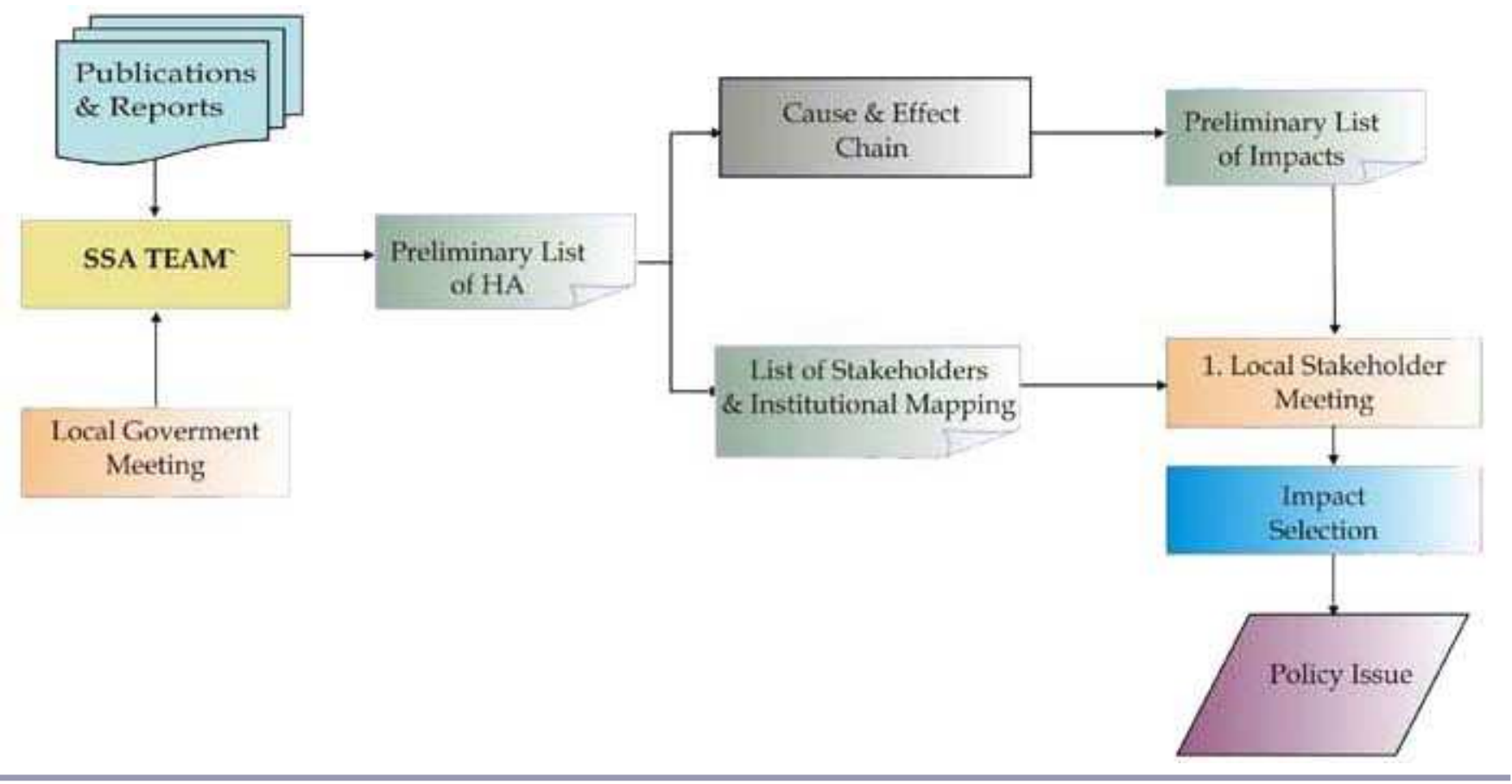

prepared and presented in subsequent small group meetings. An electronic communication tool was used for information dissemination to other stakeholders.

\section{Izmit Bay water quality}

The coupled circulation-ecosystem model was initially used to simulate SDD in response to present-day nitrogen loads so that the model performance could be verified against observations. The comparison of observed and simulated present-day SDD (Fig. 10) showed that the model was able to capture the seasonal variability in seawater transparency relatively well, however, it overestimated SDD in early and mid-summer periods. Spatially, water turbidity can be patchy in space, especially when caused by shoreline sources. In this case, where the SDD observations did not have sufficient spatial coverage to compare with the spatial average SDD from the model, some of the discrepancy is expected.

The preliminary run forced with present-day loads was deemed reasonable enough to carry out separately the scenario simulations concerning the reduction in domestic loads and runoff loads. For the scenario where all domestic wastewater is subjected to the advanced treatment, a better increase in
Fig. 10. Time evolution of simulated SDD in response to present-day nitrogen loads and two scenarios involving separately reduced domestic (scenario 1) and river (scenario 2) loads. Observed SDD values are marked by diamond symbols.

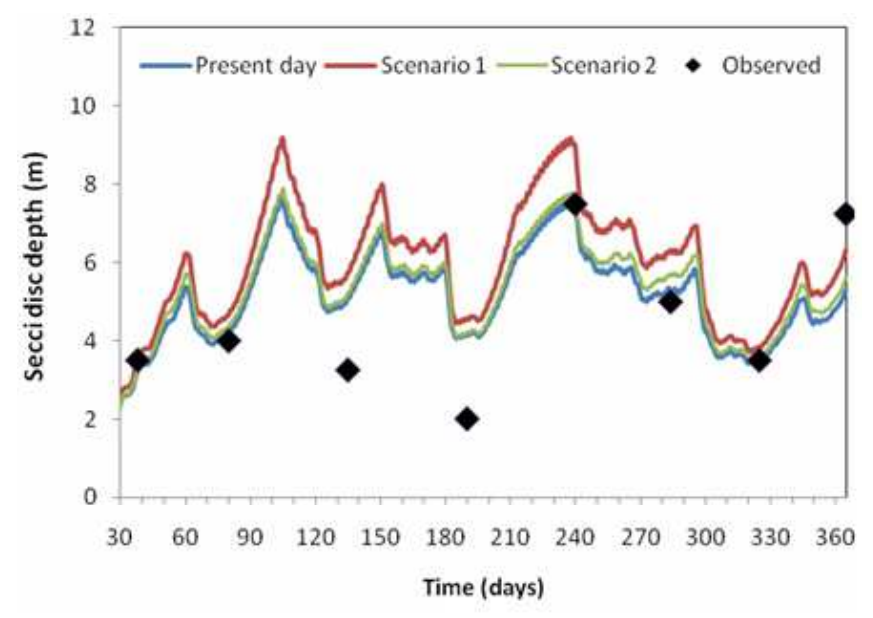

SDD was obtained compared with the scenario for reduction of runoff loads (Fig. 10). The magnitude of positive change is concentrated especially around the episodes of relatively higher quality seawater occurrence. Secchi disk depth 
improved almost $2 \mathrm{~m}$ at the beginning of summer, and around $1 \mathrm{~m}$ throughout the summer months. This constituted approximately $20 \%$ improvement for this particular time of the year with greater recreational and touristic activities. The simulated SDD values provide a direct link to the socioeconomic assessments.

\section{Socioeconomic assessments}

\section{Hedonic pricing analysis}

The previous studies mentioned in the method section showed that water quality can significantly affect property prices and provide insight for the Izmit Bay study site application.

Among different variables used to describe the physical properties of a house, only the size of an apartment was statistically significant in influencing the price of an apartment, but the ecological parameter of SDD was also statistically significant (Table 1). The following formula defines price, $\mathrm{P}$, as a function of $\mathrm{S}$ and SDD variables:

$\mathrm{P}=-69,9+955 \mathrm{~S}+30,1(\ln \mathrm{SDD}) ; R^{2}=0.50, F=85.4[1]$

Where $\mathrm{P}$ is the sales price of an apartment in TL, $\mathrm{S}$ is size of an apartment in square meters, and SDD is the transparency of water in meters. The number of observations is 174 .

The SDD or water clarity varied between 2 and $12 \mathrm{~m}$ for the locations examined in the present study. Water clarity is expressed as the natural $\log$ in the above equation to reflect the nonlinear relationship between price and water clarity (Fig. 11). It is assumed that, at lower levels of water clarity, property owners are willing to pay more for a $1-\mathrm{m}$ improvement in clarity than are owners who live near water that is relatively clear. In fact, changes in clarity occurring above $4 \mathrm{~m}$ are not as visibly noticeable as are changes in clarity below this threshold (Smeltzer and Heiskary 1990), supporting the assumption that the relationship between property prices and water clarity is nonlinear.

Table 1. Regression analysis

\begin{tabular}{lcccc}
\hline \hline & Coefficient & Standard Error & $t$ Stat & $P$ value \\
\hline Intercept & $-69,9$ & 20,5 & -3.42 & 0.0008 \\
S & 955 & 84 & 11.4 & $9 \mathrm{E}-23$ \\
Ln SDD & 30,1 & 10,1 & 2.97 & 0.003 \\
\hline
\end{tabular}

Thus, it can be inferred that an increase in water clarity from 2 to $3 \mathrm{~m}$ would increase the price of the average apartment (ca. $450 \mathrm{EUR} / \mathrm{m}^{2}$ ) by EUR $6.0 / \mathrm{m}^{2}$, whereas an increase from 5 to $6 \mathrm{~m}$ would only increase the average apartment price by EUR $2.3 / \mathrm{m}^{2}$.

\section{Contingent valuation survey: determination of willingness to} pay

The CV survey was conducted in June 2009 on 130 respondents, a relatively small sample size (due to budget constraints). The aim was to evaluate how the water quality has changed people's habits and how they will change with pollution abatement. Also, people were asked directly to state their WTP for clear water and what price they were willing to pay for clear water. Clear water was defined at the beginning of the questionnaire in terms of a transparency threshold value given in the bathing water standards. The questionnaire answers indicate that $55 \%$ of the participants are willing to pay for better water quality. A reason for this relatively low level of willingness may be that people do not trust that abatement measures will be effective after living many years in this polluted environment. The average WTP for abatement has been calculated as EUR 18.7 per capita per year, which translates into a total benefit of EUR 13 million for a coastal population of 733,051 people. The average willingness to pay per household was generalized for the inhabitants of the whole region (for more info, see: http://www.spicosa.eu/studysites/i ndex.htm).

Fig. 11. The logarithmic relationship between SDD and real-estate value as obtained from Equation 1.

Development of Price With Respect to SDD

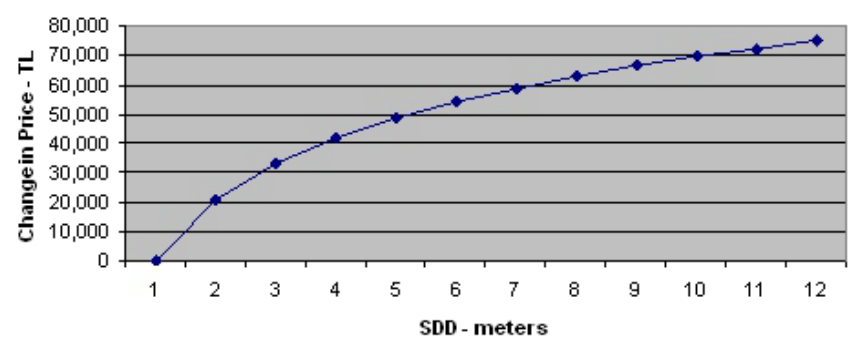

Cost-benefit analysis

Cost-benefit analysis was used to determine the costs and benefits of the proposed and simulated scenarios. Here, we present its application to the first scenario, which involved upgrading the two primary WWTPs by adding nitrogen removal facilities to the already existing systems.

According to the findings of a previous project conducted by the Marmara Research Center, the total cost (the sum of investment and operating costs) of treating $1 \mathrm{~m}^{3}$ of wastewater in the Izmit Bay is EUR 0.25. It was a useful practice to compare the unit cost of treatment with consumers' WTP for the service of wastewater treatment. To convert the annual WTP figure of EUR 18.7 into WTP for the treatment of $1 \mathrm{~m}^{3}$ of wastewater, the annual per capita water consumption (knowing that consumers are billed on the basis of the water they consume) must be estimated. We have estimated a water consumption of $120 \mathrm{~L}$ per capita per day, the annual amount 
of water consumed by an individual would be $43.8 \mathrm{~m}^{3}$. This meant a WTP of EUR $0.43 / \mathrm{m}^{3}$, which exceeds the total cost of EUR $0.25 / \mathrm{m}^{3}$. Therefore, our results indicated that the benefit of treating the wastewater in the Izmit Bay is more than the cost of treatment (for more info, see: http://www.spi cosa.eu/studysites/index.htm).

\section{DISCUSSION}

Environmental economics has a very important role to play in the development of both sustainable ICZM policies and indicators for sustainability (Bruntland 1987, Alberti 1997, United Nations Environment Programme (UNEP) 1999, MEA 2003). Unfortunately, in Turkey at present, there is a lack of knowledge and appreciation of the rudiments of environmental economics among environmental managers, including those responsible for managing coastal zones. Relevant aspects of environmental economics were included in this study for the first time in this region, described in a way that is easily communicated to coastal zone managers. Various socioeconomic indicators were used to make a cost-benefit analysis of the scenario options. We selected the indicators for their functional importance and the availability of data, e.g., real-estate value. We compared coastal housing in the bay and estimated past economic benefits. The HPA results showed that degraded water quality in Izmit Bay, as indicated by decreased water transparency, reduces real-estate values. The preliminary calculations indicated that there is an economic benefit, in the form of higher real-estate values, to be gained from improved water quality and increased transparency. For example, the cost-benefit analysis for the first scenario option indicated that the benefit of treating the wastewater in Izmit Bay is more than the cost of treatment.

In Turkey, municipalities are responsible for the construction and operation of WWTPs. The elected municipal administrators usually prefer to use the limited municipal budget on infrastructure projects that are more visible to the general public, such as parks, sports or cultural centers, recreation, roads, and the like. These governing bodies also try to avoid imposing high taxes and fees on the public. Wastewater treatment plants are costly projects that require prioritized investment, and the results may not be directly and immediately visible to the towns' residents. Turkey's EU accession policies and NEL require the local authorities to establish and operate WWTPs with certain deadlines. The same law also gives municipalities the power to distribute the cost of the plants to the public using the "user (polluter) pays principle."

For the Izmit Bay example, the impact of anthropogenic pressures on the bay is quite obvious both from results of observations and modeling. The bay is a large coastal water body with significantly restricted seawater renewal, and this study showed by simulation that wastewater treatment should be assigned a very high priority in the list of near-future investments for the coastal zone. It is evident from scenario simulations that advanced treatment of all domestic wastewater stands as a priority for the rehabilitation of Izmit Bay coastal system.

Contingent Valuation studies have been conducted on water quality problems in different part of Europe. Some of them have focused on the Baltic Sea (Soderquvist 1995, Markowska and Zylic 1999). Le Goffe (1995) used this technique in measuring the benefits of reducing eutrophication in coastal waters of Brest, France. Stoltel et al. (2003) investigated how harmful algal blooms impact on tourism in Europe. Machado and Mourato (1998) used the same method to determine the value of a reduction in health risks associated with recreatation in polluted marine waters along the Estroil coast, Lisbon, Portugal. Jones et al. (2007) conducted a CV survey to evaluate the benefits deriving from the improvement of the seawater quality around the islands in the northeast Aegean Sea. To our knowledge, this technique has not been applied previously to water quality problems in Turkey.

As also shown in this study, the water quality of Izmit Bay greatly influences the lives of local inhabitants, and they are willing to improve their environment, even if they have to pay for it. This is clear both from the survey results and the hedonic pricing analysis, where people pay more to live in houses close to clear waters. It would be useful to repeat this study in other coastal regions to compare the results and use them to better inform policy makers and local authorities so they can make well-informed decisions. In this way, they will become aware that their efforts are visible to the public and that, in contrast to what they usually think, the public is ready to pay for services that will markedly improve their environment.

The seas and coasts are of great spiritual importance to many people around the world, and such values are difficult to quantify (intrinsic value) (Moran and Pearce 1994). People who do not live around the bay may not be using its coast, but simply knowing that it exists (existence value) may be valuable for them. We may put low economic value today on Izmit Bay, but it may be valuable tomorrow because of its host species or habitat types that may turn out to have value or that may become rare and endangered in the future. This gives it a high option value. Likewise, we desire to preserve the environment for the use of future generations (bequest value) (Moran and Pearce 1994).

\section{CONCLUSION}

Economic and social assessment methodologies developed in this project were tested in the complex system of Izmit Bay. This features multiple interests, such as different uses or claims for non-use benefits. Furthermore, a high level of uncertainty and lack of knowledge on the social and economic dimension of the Izmit Bay system are part of the problem and constitute a big obstacle for ICZM efforts. It is commonly held that Izmit Bay was once rich in natural and cultural assets. Today, it is 
still under the influence of strong and diversified anthropogenic pressures. The productive and assimilative capacity of its ecosystem and the esthetic value of its landscapes have been affected in a way that it is undesirable to the inhabitants and have economic costs.

The SAF experience provided positive results for the development of stakeholder-based coastal management in Izmit Bay in several ways:

- By enhancing understanding of its complexity as a coastal zone system, by the possibility of improving the monitoring of its status in a more systematic way, and by pursuing the use of simulation analysis to evaluate ESE impacts.

- Stakeholder involvement in the issue prioritization process for this study is an important step forward in establishing a dialog between the public and local government. It provided a common and simple language facilitating communication among stakeholders.

- The CBA applied in this study showed the benefit of treating the wastewater in the Izmit Bay is more than the cost of treatment. The CV survey evaluated both use and non-use benefits deriving from the improvement of the water quality of the Bay. The HPA showed that increased water transparency in Izmit Bay significantly affects property prices in this coastal area.

The SAF application has had a positive effect on policy makers and urban planners concerning the usefulness of science and policy integration for more effective and sustainable management of the coastal zone. The Kocaeli Metropolitan Municipality considers the first scenario as implementable, and they are including this in their next investment program. Ongoing projects with the Municipality, such as water quality monitoring in Izmit Bay and rivers, regard the SAF simulation analysis as important for understanding how the water quality improves with the upgrading of the WWTPs, and they have expecting further fruitful collaboration with TUBITAK MRC. Electronic communication will allow us to continue the working relationships that we formed during our SAF application with other stakeholders, including regional and central NGOs, universities, and governmental organizations. The Ministry of Environment would also like to use the SAF for issues concerning the Marmara Sea coastal system, e.g., a proposal on "sustainable fisheries in the Marmara Sea" is being prepared.

Responses to this article can be read online at: http://www.ecologyandsociety.org/vol17/iss3/art40/ responses/

\section{Acknowledgments:}

We acknowledge the European Union's financial support through the Integrated Project SPICOSA, under the 6th Framework Programme. We would like to thank to David Hadley and Jose Perez for their literature suggestions. Furthermore, we are grateful to all stakeholders for their contributions and remarks. We would also like to thank Dr. Patricia Balci for her corrections on the text. Finally, we gratefully acknowledge Tom Hopkins for his endless encouragement, supervision, and patience during the project.

\section{LITERATURE CITED}

Alberti, M. 1997. Measuring urban sustainability. Environmental Impact Assessment Review 16(4-6):381-424. [online] URL: http://www.sciencedirect.com/science/article/pii/ $\underline{\text { S0195925596000832 }}$

Alberti, M., and Susskind, L., editors. 1996. Measuring urban sustainability. Special issue. Environmental Impact Assessment Review 16(4-6):213-447.

Algan, N. 2000. The significance of international legislation in ICZM, Turkish Journal of Marine Sciences 6(1):55-69

Aligica, P. D. 2006, Institutional and stakeholder mapping: frameworks for policy analysis and institutional change. Public Organization Review 6:79-90. http://dx.doi.org/10.1007/ $\underline{\mathrm{s} 11115-006-6833-0}$

Avaz, G., S. Tugrul, F. Kucuksezgin, I. Tan, and E. Kuzyaka. 2011. Management of the urban wastewater in Turkish coasts: determination of hot spots and sensitive areas and development of the investment plans project. Third Progress Report, TUBITAK MRC, Gebze-Kocaeli, Turkey. (In Turkish.)

Balkis N. 2003. The effect of Marmara (Izmit) earthquake on the chemical oceanography of Izmit Bay, Turkey. Marine Pollution Bulletin 46:865-878. http://dx.doi.org/10.1016/S00 25-326X(03)00063-8

Basturk, O., S. Tuğrul, M. Sunay, T. Balkas, E. Morkoç, O. S. Okay, and A. Bozyap. 1985. Determination of oceanographic characteristics and assimilation capacity of Izmit Bay. NATO TU-WATERS Project, May 1984-May 1985 period. TUBITAK-MAM Publ., Gebze, Turkey.

Basturk O., S. Tuğrul, A. Yilmaz, and C. Saydam. 1990. Health of the Turkish Straits: chemical and environmental aspects of the Sea of Marmara. METU-Institute of Marine Sciences, Tech. Rep., No. 90/4, Erdemli, Içel, Turkey.

Berkes F., and C. Folke, editors. 1998. Linking social and ecological systems, management practices and social mechanisms for building resilience. Cambridge University Press, Cambridge, UK. 
Brashares, E. 1985. Estimating the instream value of lake water quality in southeast Michigan. Dissertation, University of Michigan, Ann Arbor, Michigan, USA.

Bruntland, G., editor, 1987.Our common future: the World Commission on Environment and Development. Oxford University Press, Oxford, UK.

de Groot, R. S. 1992. Functions of nature; evaluation of nature in environmental planning, management and decisionmaking. Wolters-Noordhoff, Groningen, The Netherlands.

Dixon, J. A., L. F. Scura, R. A. Carpenter, and P. B. Sherman. 1994. Economic analysis of environmental impacts. Earthscan, London, UK.

Ediger, D., Ç. Beken, L. Tolun, V. Tüfekçi, H.Tüfekçi, M. Mantikçi, and H. Atabay. 2009. Monitoring of water quality and land-based inputs in the Izmit Bay. TÜBITAK/MAM (508G203) Project final report, ÇE.02.02, Gebze, Kocaeli, Turkey. (In Turkish.)

European Commission. 1999. Towards a European integrated coastal zone management (iczm) strategy. General Principles and Policy Options. EC Official Publ. Luxembourg.

European Commission. 2000. The EU Water Framework Directive - integrated river basin management for Europe. Directive 2000/60/EC, Official Journal (OJ L 327). European Commission, Brussels, Belgium. [online] URL: http://ec.euro pa.eu/environment/water/water-framework/index en.html

European Commission. 2002. Recommendation of the European Parliament and of the Council of 30 May 2002 concerning the implementation of Integrated Coastal Zone Management (ICZM). 2002/413/EC. OJ 6.6.2002, L148/24. European Commission, Brussels, Belgium.

European Commission. 2008. Marine strategy framework directive on establishing a framework for community action in the field of marine environmental policy. Directive 2008/56/ EC. European Commission, Brussels, Belgium.

Garrod, G., and K. G. Willis, 1999. Economic valuation of the environment: methods and case studies. Edward Elgar, Cheltenham, UK.

Government of Turkey. 2001. Vision 2023. Science and Technology Strategy Project by the Supreme Council of Science and Technology of Turkey, Istanbul, Turkey.

Hopkins, T. S. 2001. Thermohaline feedback loops and natural capital. Scientia Marina 65:233-258.

Hopkins, T. S., D. Bailly, R. Elmgren, G. Glegg, A. Sandberg, and J. G. Støttrup. 2012. A systems approach framework for the transition to sustainable development: potential value based on coastal experiments. Ecology and Society 17(3): 39. http://dx.doi.org/10.5751/ES-05266-170339
Hopkins, T.S., D. Bailly, and J. G. Støttrup. 2011. A systems approach framework for coastal zones. Ecology and Society 16(4): 25. http://dx.doi.org/10.5751/ES-04553-160425

Jones, N., C. M. Sophoulis, and C. Malesios. 2007. Economic valuation of coastal water quality and protest responses: a case study in Mitilini, Greece. Journal of Socio-Economics 37 (6):2478-2491. http://dx.doi.org/10.1016/j.socec.2007.06.002

Kelly, K. L. 1998. A systems approach to identifying decisive information for sustainable development. European Journal of Operational Research 109:452-464. http://dx.doi.org/10.1 016/S0377-2217(98)00070-8

Lancaster, K. 1966. A new approach to consumer theory. Journal of Political Economics 84:132-57. http://dx.doi.org/1 $\underline{0.1086 / 259131}$

Le Goffe, P. 1995. The benefits of improvements in coastal water quality: a contingent approach. Journal of Environmental Management 45(4):305-317. http://dx.doi.org /10.1006/jema.1995.0078

Machado, F., and S. Mourato. 1998. Improving the assessment of related health impacts: evidence from coastal waters in Portugal. First World Congress on Environmental and Resources Economics, 25 -27 June 1998, Venice, Italy.

Markowska, A., and T. Zylicz. 1999. Costing an international public good: the case of Baltic Sea. Ecological Economics 30:301-316. http://dx.doi.org/10.1016/S0921-8009(98)00138-4

Mayers, J., and S. Vermeulen. 2005. Stakeholder influence mapping. International Institute for Environment and Development, London, UK.

Michael, H. J., K. J. Boyle, and R. Bouchard. 1996. Water quality affects property prices. A case study of selected Maine lakes. Maine Agricultural and Forest Experiment Station Report No. 398. University of Maine, Orono, Maine, USA.

Millennium Ecosystem Assessment (MEA). 2003. Ecosystems and human well-being: a framework for assessment. Island Press, Washington, D.C., USA.

Mitchell, R. C., and R. T. Carson. 1989. Using surveys to value public goods: the contingent valuation method. Resources for the Future, Washington, D.C., USA.

Moran, D., and D. Pearce. 1994. The value of biodiversity. World Conservation Union, Biodiversity Programme, Earthscan Publications, London, UK.

Morkoç, E., T. Legoviç, O. Okay, H. Tüfekç, V. Tüfekç, L. Tolun, and F. Karakoc. 2007. Changes of oceanographic characteristics and the state of pollution in the Izmit Bay following the earthquake of 1999. Environmental Geology 10:254. 
Morkoç, E., O. S. Okay, L. Tolun, V. Tüfekçi, H. Tüfekçi, and T. Legoviç. 2001. Towards a clean Izmit Bay. Environment International 26:157-162. http://dx.doi.org/10.1016/S0160-4120 $\underline{(00) 00103-3}$

Morkoç, E., S. Tugrul, O. S. Okay, and T. Legoviç. 1997. Eutrophication of the Izmit Bay, Marmara Sea. Croatica Chemica Acta 70:347-359.

Okay O. S, L. Tolun, F. Telli-Karakoç, V. Tüfekçi, H. Tüfekçi, and E. Morkoç. 2001. Izmit Bay ecosystem after Marmara earthquake and subsequent fire: the long-term data. Mar Pollut Bull 42:361-369. http://dx.doi.org/10.1016/S0025-326X(00)0 $\underline{0163-6}$

Ozhan, E. 2005. Coastal area management in Turkey. Priority Actions Programme Regional Activity Centre (PAP/RAC), Split, Croatia.

Pagiola, S., K. von Ritter, and J. Bishop. 2004. Assessing the economic value of ecosystem conservation. Paper no. 101, The World Bank Environmental Department, Washington, D.C., USA.

Pearce, D.W. 1993. Economic values and the natural world. Earthscan, London, UK.

Pearce D.W., and K. Turner. 1990. Economics of natural resources and the environment. First edition. Harvester Wheatsheaf, London, UK.

Polat-Beken, C.., L. Tolun, G. Avaz, A. Dönertas, D. Ediger, F. Telli-Karakoç, and S. Tuğrul. 2009. DPSIR applied to 4large Turkish coastal cities: Mersin, Antalya, Izmir and Kocaeli. Proceedings of the International Workshop on the Impact of Large Mediterranean Coastal Cities on Marine Ecosytems. Alexandria, Egypt, 10-12 February 2009. [online] URL: http://www.ifremer.fr/medicis/documents/pdf/ Proceedings Alexandrie final.pdf

Polat-Beken, Ç., V. Tüfekçi, B. Sözer, M. Mantikçi, H. Atabay, L. Tolun, E. Yildiz, S. Hocaoğlu, D. Ediger, F. TelliKarakoç, and A. Olgun. 2010. Investigation of factors controlling the marine musilage/mucus formation with bioassay techniques. Third interim report. TUBITAK (108Y083) Project, Gebze, Kocaeli, Turkey.

Smeltzer, E., and S. A. Heiskary, 1990. Analysis and application of the lake survey data. Lake and Reservoir Management 6:109-118. http://dx.doi.org/10.1080/07438149 $\underline{009354701}$

Soderqvist, T. 1995.The benefits of reduced eutrophication of the Baltic sea: a contingent valuation study. Stockholm School of Economics and Beijer International Institute of Ecological Economics, Stockholm, Sweden.

Stoltel, W., S. Scatasta, E. Graneli, H. P. Weikard, and E. van Ierland. 2003. ECOHARM: The socio-economic impact of harmful algal blooms in European marine waters. Report
EVK3-CT-2001-80003. European Commission, Brussels, Belgium.

Tett, P., A. Sandberg, and A. Mette, editors. 2011. Sustaining coastal zone systems. Dunedin Academic Press, Edinburgh, UK.

The Economics of Ecosystems and Biodiversity (TEEB). 2010. Mainstreaming the economics of nature: a synthesis of the approach, conclusions and recommendations of TEEB. TEEB, Geneva, Switzerland.

Tolun, L., F.T. Karakoç, B. Henkelmann, O. S. Okay, and K. W. Schramm. 2007. PCB pollution in Izmit Bay (Marmara Sea) mussels after the earthquake. NATO, Advanced Research Workshop on the Fate of Persistent Organic Pollutants in the Environment. 24-27 April 2007, Istanbul, Turkey. http://dx.d oi.org/10.1007/978-1-4020-6642-9 10

Tolun, L., E. Morkoç, V. Tüfekç, , F. Telli-Karakoç, O. Okay, D. Karakas, H. Tüfekci, A. Olgun, F. Karakoç, 2002. Effects of natural phenomenon and land based pollutants to the coastal waters: Izmit Bay and Dil Deresi as a special area. Final Report, Project no: 5017509. TUBITAK, MRC, EMSRI, Gebze, Kocaeli, Turkey.

Tolun, L., O.S. Okay, V. Tüfekçi, F. Telli Karakoç, D. Karakas, H. Tüfekçi, A. Olgun, E. Morkoç. 2003. Pollution monitoring of Izmit Bay (Turkey): contribution of the landbased sources after the earthquake. Proceedings of the Sixth International Conference on the Mediterranean Coastal Environment, MEDCOAST 03, 7-11 October 2003, Ravenna, Italy.

Tuğrul, S., E. Morkoç and O. Okay. 1989. Wastewater treatment and disposal studies: the determination of oceanographic characteristics and assimilation capacity of the Izmit Bay. Pages 183-250 in Final report, Chemical Engineering Research Department Subproject 8, TUBITAKMRI, Gebze, Kocaeli, Turkey.

Turkish Official Gazette. 1983. National environment law No. 2872, 11/08/1983 no:181132. Istanbul, Turkey.

Turkish Statistical Institute (Turkstat). 2009. The results of address based population registration system. URL: http://w ww.turkstat.gov.tr/PreHaberBultenleri.do?id=6178.

Turner, K. 1993.Sustainable environmental economics and management, principals and practice. Wiley, New York, New York, USA.

United Nations Environment Programme (UNEP). 1999. Report of the workshop on indicators for sustainable development in the Mediterranean region. Expert Group Meeting, 10-11 May 1999, Sophia, Bulgaria.

Vanderlinden, Jean-Paul. 2009. SPICOSA's WT1.1 leader. SPICOSA stakeholder-policy mapping users' manual, complete version with worked examples. Project deliverable 1.6, SPICOSA, Plouzane Cedex, France. 